\title{
Running Head: Reading Comprehension: Reviving the Sentence Verification Technique
}

Nisha Vidyasagar* and Sudha Bhogle ${ }^{\dagger}$

\section{Abstract}

Reading success is largely determined by reading comprehension. Thus accurate assessment of reading comprehension is necessary to identify those who require remediation and to plan future instructions in classrooms. Sentence verification technique (SVT) is one of the methods of assessing comprehension and can function as a diagnostic tool in reading assessment. The aim of the current study was to determine whether the SVT could detect gender and grade differences in reading comprehension. The study targeted 1091 elementary grade students comprising both boys and girls who were assessed using the SVT. The students read two text passages selected according to their grade level and responded to four sentence types - original, paraphrase, meaning change and distracter sentences. Independent sample $t$ test highlighted that girls were significantly better than boys with regard to reading comprehension ability. One way analysis of variance to analyse grade differences indicated that there were significant improvements in reading comprehension ability with higher grades, thus highlighting the sensitivity of SVTs in detecting developmental changes in reading comprehension. The findings of this study emphasize the diagnostic potential of the SVTs with regard to identifying children with reading comprehension

\footnotetext{
* Research Scholar in Department of Psychology, Christ University, Bangalore; nishavidyasagar@hotmail.com

† Professor of Psychology and Head, Student Solution, Eduquity Career Technologies, Bangalore
} 
difficulties which in turn would help in planning their remediation. These SVTs can be easily developed by school teachers and other non-psychometricians for the purpose of identifying students requiring assistance. The paper will discuss the findings, purpose and uses of SVT along with its classroom implications.

Keywords: Reading comprehension research; Reading assessment; reading comprehension in the elementary grades; Sentence verification technique

\section{Introduction}

Reading is a crucial foundation for a successful lifetime learning experience in a variety of disciplines including those not relying heavily on it like mathematics. Research has pointed that those children who do not learn the basics of early reading are unlikely to learn them at all (Moats, 1994). In fact, many children who read at the third grade level in grade III will not automatically become proficient readers in later grades unless teachers explicitly teach strategies for reading comprehension, especially for poor comprehenders (Bishop, Reyes, \& Pflaum, 2006 as cited in Hess, 2007).This paper attempts to highlight the importance of readingcomprehension and its assessment in educational settings.

\section{Reading Comprehension}

Comprehension is defined as "intentional thinking during which meaning is constructed through interactions between the text and the reader" (Harris \& Hodges, 1995 as cited in National Reading Panel, 2000). Rice (2009) conceptualized comprehension as a problem solving process rather than a particular outcome or a product. Through this process the reader deliberately and stretegically interacts with the text to construct meaning. Hence, the meaning a reader derives from the text is influenced by his or her own knowledge (including knowledge of language and print), experience and perceived purpose for reading. This meaning making process has been termed by Durkin (1993, as cited in Rice, 2009) as "the essence of reading". 


\section{Gender and Developmental Differences in Reading}

Girls have been known to consistently outperform boys in reading skills and this gender difference holds true globally. For example, in a meta-analysis of sex differences in reading achievement conducted by Lietz (2006), it was found that in many countries girls in secondary school performed 0.19 standard deviation units above boys. "Girls not only tended to attain higher reading scores than boys, they were also more aware of strategies for understanding, remembering and summarising information," according to Professor Geoff Masters, CEO of ACER (Dhar, 2012).

Reading comprehension is known to follow a developmental progression. Chall (1983 as cited in Anders, 2002), is one of the notable educators to come up with an understanding on the development of reading comprehension with the help of an age related stage theory ranging from stage zero (Birth to 6 months) to stage five (18 years and above). The key stages during which reading comprehension strategies develop are stages 1-3 as reflected in Figure 1 . These stages reflect that children tend to progress from understanding the basics of the grapheme-phoneme connection to reading and processing informational text. Problems with any of these stages would in turn lead to reading difficulties which thereby would interfere with academic mastery.

\begin{tabular}{|l|l|}
\hline Stages & Description \\
\hline $\begin{array}{l}\text { Stage 1: Initial reading or } \\
\text { decoding stage; Grades 1-2; } \\
\text { Ages 6-7 }\end{array}$ & $\begin{array}{l}\text { Children develop rules for letter and sound } \\
\text { correspondence which continues from stage 0 }\end{array}$ \\
\hline $\begin{array}{l}\text { Stage 2: Confirmation, } \\
\text { Fluency, Ungluing from the } \\
\text { print; Grades 2-3; Ages 7-8 }\end{array}$ & $\begin{array}{l}\text { Reader becoming fluent. Not reading to learn } \\
\text { new information but reading to confirm what } \\
\text { is already known. }\end{array}$ \\
\hline $\begin{array}{l}\text { Stage 3: Reading for } \\
\text { learning the new: A first } \\
\text { step; Grades 4-8; Ages 9-13 }\end{array}$ & $\begin{array}{l}\text { Reading stories and informational text about } \\
\text { what is already known, or reading simple text } \\
\text { with only one perspective and limited } \\
\text { technical complexities. }\end{array}$ \\
\hline
\end{tabular}

Fig. 1. Stages of reading development (Chall, 1983 as cited in Anders, 2002) 


\section{Reading Comprehension Assessments: A Critical Examination}

The important role that comprehension plays in reading highlights the need for adeqaute and effective reading assessments to aid in the early identification of children with reading difficulties. There are an abundance of reading assessments which rely heavily on basic literacy skills, word recognition and decoding. However, there is a dearth of assessments targetting reading comprehension which forms a separate entity by itself and is often neglected in the general reading assessments.

The researcher's experiences and observations in the field of educational testing has led to the conclusion that school teachers mostly conduct assessments on reading comprehension in an informal manner in the form of observations, retelling, answering questions posed from the text or expressing through writing. These practices are unfortunately subjective, qualitative and not standardized.

McNamara (2011), has argued in his paper regarding the importance of access to assessments that are indicative of the students' ability to draw inferences and build coherent mental representations of the text. Educators also need access to comprehension assessment techniques that are likely to reflect a student's deep understanding of the material. Different types of assessments pull out different types of understanding. Multiple choice questions generally give a superficial level of understanding of the readers recognition of the text and it targets a restricted range of text. Cloze passages assess comprehension only within sentences based on word associations (Shanahan, et al, 1982 as cited in McNamara, 2011). McNamara's review on reading comprehension assessment has highlighted that students' likelihood of success in reading and comprehension depends on the material that is read and the task that is completed during or after reading this material (Fletcher, 2006 as cited in McNamara, 2011). 


\section{Sentence Verification Technique: A Reading Comprehension Measure}

A review of the existing assessment methods (formal as well as informal) suggests that there appears to be a strong need for an assessment that is relatively simpler and easy to use for the purpose of easy identification of children requiring assistance at the classroom level itself. Sentence verification technique is one such method which was developed by Royer et al., in 1987. This technique is based on the theoretical notion that 'Language comprehension is a constructive process in which an incoming linguistic message, the recipient's prior knowledge, and the environmental context in which the message is received all interact to determine the nature of the comprehended material' (Bransford \& McCarrell, 1974 as cited in Royer, et al., 1979, p.2).Moreover, the memorial representation of this comprehended message is in a form which preserves the meaning of the message but not its surface structure (Sachs, 1974 as cited in Royer, et al., 1979).

The sentence verification technique is one method which adopts the above perspective and tests whether the sentence has been preserved in memory in a form where the meaning has been retained and not just the superficial structure. In this technique, students have to read select text passages and then distinguish between four types of sentences which either mean the same as the original sentences or are different in meaning. This technique has an advantage over other comprehension assessments in that it does not rely on inferential reasoning ability and on general knowledge. It measures passage comprehension and not sentence comprehension.

There appearedto be a dearth of studies using this technique in Indian classroom settings and the present study hoped to fill this lacuna. The main aims of the research were to assess the role of SVTs in detecting differences in reading comprehension between gender and grades and to understand the relationship between the SVTs and reading achievement in schools. Specific research questions addressed by the study were:

1. Can sentence verification technique, a measure of reading comprehension, detect differences between boys and girls? 
2. Can this technique detect developmental differences between the students of three different grades?

\section{Method}

Hypotheses. It was hypothesised that:

1. Girls would perform better than boys in reading comprehension as assessed by SVTs.

2. Higher grade children would perform better than the lower grades on reading comprehension as assessed by SVTs.

3. Reading comprehension as assessed by the SVT would be positively and significantly correlated with reading achievement in schools.

Participants. The study employed a cross-sectional design and targetted 1091 children from elementary grades studying in different schools in Bangalore city which followed the ICSE board.

Purposive sampling method was used for the selection of the sample of students from $3^{\text {rd }}, 4^{\text {th }}$ and $5^{\text {th }}$ grades from 4 schools. Table 1 highlights the sample description. Children ranged in age from eight years to fourteen years $(M=9.8$ years; $S D=1.06)$. Girls comprised $47 \%$ of the sample $(n=513)$ and boys comprised $53 \%(n$ $=578$ ). All the children were from english medium schools and were selected during 2011-2012 academic year.

Table 1 Sample Description

\section{Sample Description}

\begin{tabular}{|c|c|c|c|}
\hline Grades & $\mathbf{N}$ & Gender & Mean age and SD \\
\hline \multirow{2}{*}{3} & 365 & 189 Girls & $8.8 \pm 0.64$ \\
\cline { 3 - 3 } & & 176 Boys & \\
\hline \multirow{2}{*}{} & 363 & 158 Girls & \multirow{2}{*}{$9.8 \pm 0.71$} \\
\cline { 3 - 3 } & & 205 Boys & \\
\hline \multirow{5}{*}{3} & 363 & 165 Girls & \multirow{2}{*}{$10.8 \pm 0.7$} \\
& & 197 Boys & \\
\hline
\end{tabular}

Measures used. Measures used to fulfill the objectives of the study are described. 
1. Personal Information sheet - Demographic details of the children were collected.

2. Sentence verification technique - This was used for the assessment of reading comprehension. This technique was developed as part of a general reading assessment for identification of children with reading difficulties for another on-going research. Two text passages were selected according to the sample grade level. Twelve sentences of the forced-choice type (Yes/No) were developed for each of the passages based on the following four sentence types:

a. Originals- these sentences were exact copies of the passage sentences

b. Paraphrases- word changes were done while still retaining the meaning of the sentences

c. Meaning Change- one or two word changes were done to create a sentence with a different meaning

d. Distracters- sentences were created which were consistent in theme with the original passage but were different with regard to meaning and wording

English language performance - The recent assessment marks in both literature and language as achieved in the school were considered.

Procedure: ICSE English text books were referred to and passages selected following which SVTs were developed. Elementary grade teachers were consulted regarding the appropriateness of the selected passages. Pilot testing of the test material was done on two children from the $3^{\text {rd }}$ and $4^{\text {th }}$ grades. The mode of administration of the assessment was group and it was conducted within the classroom setting during the school hours. The assessment took approximately 30 minutes to complete. The children had to silently read each of the two passages and respond to the forced choice (Yes/No) sentences that followed the passages. The four types of SVTs were scored with correct answers receiving a score of 1 and incorrect answers a score of 0 . The total score as well as percentage of correct responses for each of the 4 sentence types i.e., originals, paraphrases, meaning changes and distracters were computed. The 
data obtained was statistically analysed using the SPSS 16.0 software.

\section{Results and Discussion}

The primary purpose of this study was to understand the utility of the SVTs as a reading comprehension measure in detecting significant gender and grade differences. Another sub goal was to understand the relationship between the SVTs and reading achievement in schools. The major findings of the study are discussed in this section.

\section{Gender Differences}

To address the first hypothesis, independent sample test was conducted. The performances on the whole as well as the four types of SVTs used to measure reading comprehension were the dependent variables while gender was the independent variable. The results are presented in Figure 2 and Table 2. Findings indicate that as hypothesized, girls have performed significantly better than boys on reading comprehension as a whole as well as in correctly identifying all the four sentence types (reading comprehension total score: $\mathrm{t}=5.86 ; \mathrm{p}<0.001$ ); originals: $\mathrm{t}=3.58, \mathrm{p}<0.001$; paraphrases: $\mathrm{t}=2.04, \mathrm{p}<0.05$; meaning change: $\mathrm{t}=5.05, \mathrm{p}<0.001$ and distractors: $\mathrm{t}=6.42, \mathrm{p}<0.001)$.

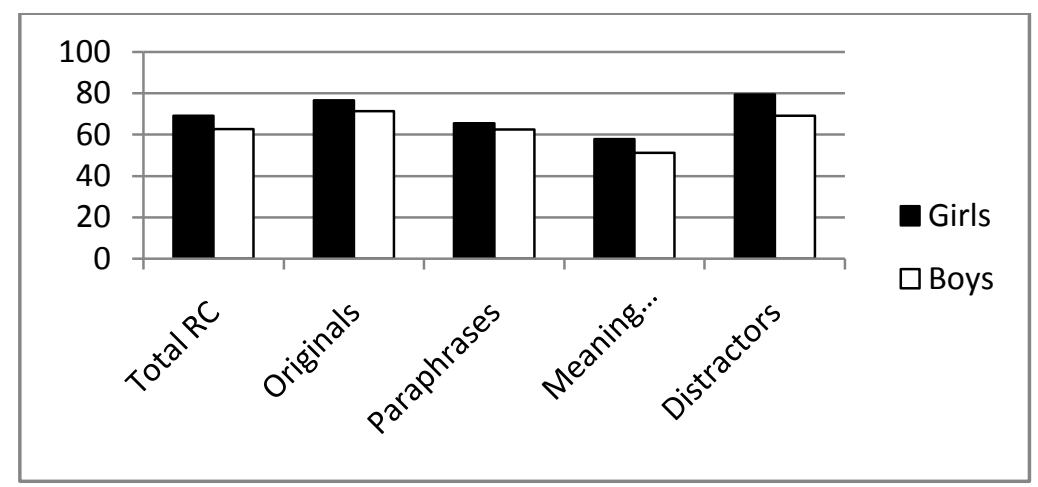

Fig. 2.Bar graph depicting the gender differences with regard to each of the four sentence types of the SVTs and total reading comprehension (RC).

This is congruent with previous researches most of which have indicated that boys have more reading problems in comparison to girls (Wheldall, 2010; Child Health News, 2004). The Programme 
for International Student Assessment (PISA) study in 2009 has also highlighted that girls outperform boys in every participating country (including India) by an average of 39 PISA score points which is equivalent to more than one year of schooling (OECD, 2010, p 7). According to the Canadian Council on Learning report (2009), girls tend to perform better than boys because of attitude and behavioural differences. The report highlighted studies which concluded that girls tend to do more out of class reading, more sharing and discussion of reading material and spend more time doing homework than boys.

Table 2-Descriptive Statistics and t Value Reflecting Gender Differences with Regard to Reading Comprehension

\begin{tabular}{|l|c|c|c|}
\hline \multirow{2}{*}{ Variables } & Girls $(N=514)$ & Boys $(N=577)$ & \multirow{2}{*}{$\mathrm{t}$} \\
\cline { 2 - 3 } & $\mathrm{M}(\mathrm{SD})$ & $\mathrm{M}(\mathrm{SD})$ & \\
\hline Total & $69.25(18.23)$ & $62.78(18.11)$ & $5.86^{* * *}$ \\
\hline Originals & $76.6(23.94)$ & $71.3(25.26)$ & $3.58^{* * *}$ \\
\hline Paraphrases & $65.6(24.78)$ & $62.5(25.74)$ & $2.04^{*}$ \\
\hline Meaning Change & $57.8(21.64)$ & $51.2(21.78)$ & $5.05^{* * *}$ \\
\hline Distracters & $79.4(25.01)$ & $69.2(27.23)$ & $6.42^{* * *}$ \\
\hline
\end{tabular}

Note. ${ }^{*} \mathrm{p}<0.05 ; * * * \mathrm{p}<0.001$

Note. ${ }^{* * *} \mathrm{p}<0.001$

\section{Grade Differences}

The second hypothesis was addressed by computing One-way ANOVAs. Figure 3 gives an overall understanding of the reading comprehension ability of the children in the three grades. This figure reflects that as expected, reading comprehension ability was found to increase with higher grades. Table 3 reflects the mean, SD and $\mathrm{F}$ ratios computed for reading comprehension as well as all the four types of SVTs with regard to each grade. There is a significant difference between the three grades with regard to reading comprehension ability $(\mathrm{F}=33.87 ; \mathrm{p}<0.001)$ as assessed using the four types of SVTs. The figures in the table indicate that with higher grades, the mean correct responses for the sentence types have also increased. Of all the sentence types, proportion of students (in all three grades) correctly identifying the "meaning change" sentence type was relatively less compared to other types indicating that this sentence type is more sensitive to comprehension of deeper 
meaning of the sentences. This is in line with Carlisle's and Felbinger's (1991, as cited in Beech, 1997) suggestion that children who do not construct a representation of meaning of the whole text would make a disproportionate number of errors on sentences requiring an understanding of the meaning of the text (e.g., distracters and meaning change types). On the other hand, the students performed relatively better on SVT types of originals and paraphrases because these sentences required only a surface representation of the textual meaning.

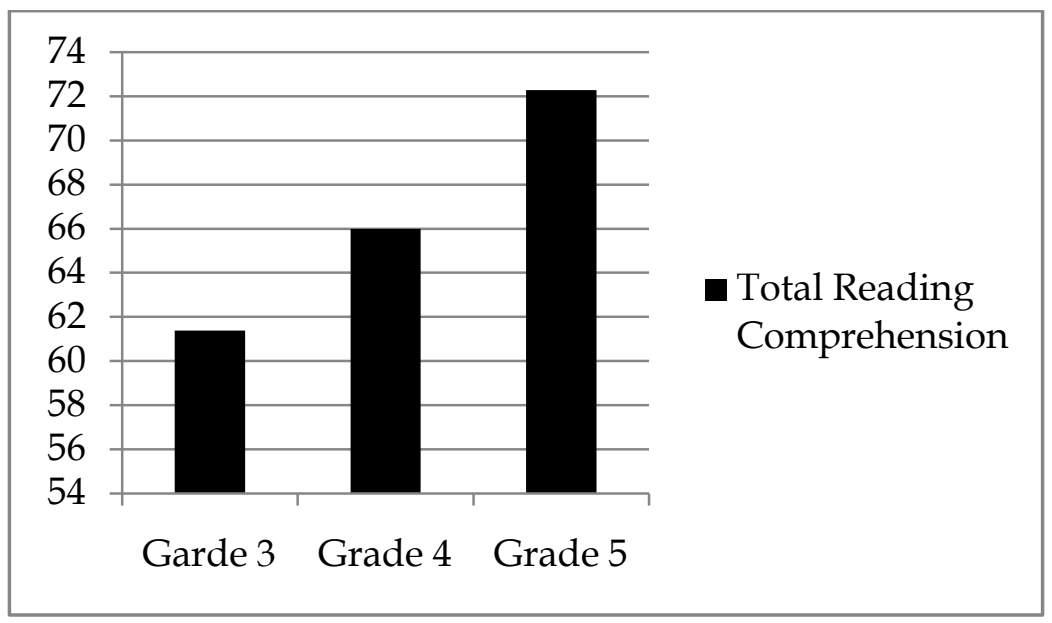

Fig. 3.Bar graph depicting the grade differences with regard to total reading comprehension score as obtained on SVTs.

Table 3- Mean SD and F Ratio for Each of the Sentence Types and Total Reading Comprehension for Each Grade

\begin{tabular}{|c|c|c|c|c|c|}
\hline Grade & Total & Originals & Paraphrases & $\begin{array}{c}\text { Meaning } \\
\text { Change }\end{array}$ & Distracters \\
\hline 3 & $61.38 \pm 18.84$ & $69.0 \pm$ & $59.8 \pm$ & $49.7 \pm 21.42$ & $67.0 \pm$ \\
& & 26.5 & 26.39 & & 27.98 \\
\hline 4 & $66 \pm 18.34$ & $73.2 \pm$ & $62.5 \pm$ & $53.6 \pm 21.41$ & $74.6 \pm$ \\
& & 25.05 & 26.51 & & 26.03 \\
\hline 5 & $72.29 \pm 16.05$ & $79.2 \pm$ & $69.8 \pm$ & $59.7 \pm 21.96$ & $80.5 \pm$ \\
& & 21.44 & 21.69 & & 24.25 \\
\hline $\mathrm{F}$ & $33.87 * * *$ & $15.64 * * *$ & $15.26 * * *$ & $19.60 * * *$ & $23.91 * * *$ \\
ratio & & & & & \\
\hline
\end{tabular}

Note. $* * * \mathrm{p}<0.001$

Post-hoc analyses were done using Bon Ferroni tests to understand the differences better with regard to each of the three grades. Table 
4 indicates that grade 5 students have performed better than the other two lower grades with regard to correctly identifying the originals, paraphrases, meaning changes and distractor sentences $(p<0.01)$. The grade 4 students on the other hand have been able to perform significantly better than grade 3 students in correctly identifying the meaning change $(p<0.05)$ and distractor sentences $(p<0.001)$ and not the original and paraphrases. The latter two sentences reflect surface level comprehension while the former two sentences indicate deeper level of understanding the text passage. Hence grade 5 students were better at comprehending the surface as well as the deeper meaning of the text in comparison to the lower grades. Grade 4 students were significantly different from grade 3 with regard to their better understanding of the deeper meaning of the text.

Table 4-Post Hoc Analysis of the SVT Variables With Regard to the Three Grades

\begin{tabular}{|c|c|c|c|c|c|}
\hline Variables & \multicolumn{2}{|c|}{ Class } & \multirow{2}{*}{$\begin{array}{c}\begin{array}{c}\text { Mean } \\
\text { difference }\end{array} \\
-4.16 \\
-10.16\end{array}$} & \multirow{2}{*}{$\begin{array}{c}\begin{array}{c}\text { Standard } \\
\text { error }\end{array} \\
1.80 \\
1.82\end{array}$} & \multirow{2}{*}{$\begin{array}{l}\text { Sig. } \\
.064 \\
.000\end{array}$} \\
\hline Originals & $3^{\text {rd }}$ grade & $\begin{array}{l}4^{\text {th }} \text { grade } \\
5^{\text {th }} \text { grade }\end{array}$ & & & \\
\hline & $\begin{array}{l}4^{\text {th }} \\
\text { grade }\end{array}$ & $\begin{array}{l}3^{\text {rd }} \text { grade } \\
5^{\text {th }} \text { grade }\end{array}$ & $\begin{array}{l}4.15 \\
-6.01\end{array}$ & $\begin{array}{l}1.80 \\
1.81\end{array}$ & $\begin{array}{l}.064 \\
.003\end{array}$ \\
\hline & $\begin{array}{c}5^{\text {th }} \\
\text { grade }\end{array}$ & $\begin{array}{l}3^{\text {rd }} \text { grade } \\
4^{\text {th }} \text { grade }\end{array}$ & $\begin{array}{c}10.16 \\
6.01\end{array}$ & $\begin{array}{l}1.82 \\
1.81\end{array}$ & $\begin{array}{l}.000 \\
.003\end{array}$ \\
\hline Paraphrases & $3^{\text {rd }}$ grade & $\begin{array}{l}4^{\text {th }} \text { grade } \\
5^{\text {th }} \text { grade }\end{array}$ & $\begin{array}{l}-2.78 \\
-9.99\end{array}$ & $\begin{array}{l}1.84 \\
1.87\end{array}$ & $\begin{array}{l}.395 \\
.000\end{array}$ \\
\hline & $\begin{array}{l}4^{\text {th }} \\
\text { grade }\end{array}$ & $\begin{array}{l}3^{\text {rd }} \text { grade } \\
5^{\text {th }} \text { grade }\end{array}$ & $\begin{array}{l}2.78 \\
-7.22\end{array}$ & $\begin{array}{l}1.84 \\
1.85\end{array}$ & $\begin{array}{l}.395 \\
.000 \\
\end{array}$ \\
\hline & $\begin{array}{l}5^{\text {th }} \\
\text { grade }\end{array}$ & $\begin{array}{l}3^{\text {rd }} \text { grade } \\
4^{\text {th }} \text { grade }\end{array}$ & $\begin{array}{l}9.99 \\
7.22\end{array}$ & $\begin{array}{l}1.87 \\
1.85\end{array}$ & $\begin{array}{l}.000 \\
.000\end{array}$ \\
\hline $\begin{array}{l}\text { Meaning } \\
\text { change }\end{array}$ & $3^{\text {rd }}$ grade & $\begin{array}{l}4^{\text {th }} \text { grade } \\
5^{\text {th }} \text { grade }\end{array}$ & $\begin{array}{c}-3.89 \\
-10.02\end{array}$ & $\begin{array}{l}1.59 \\
1.61\end{array}$ & $\begin{array}{l}.044 \\
.000\end{array}$ \\
\hline & $\begin{array}{c}4^{\text {th }} \\
\text { grade }\end{array}$ & $\begin{array}{l}3^{\text {rd }} \text { grade } \\
5^{\text {th }} \text { grade }\end{array}$ & $\begin{array}{l}3.89 \\
-6.12\end{array}$ & $\begin{array}{l}1.59 \\
1.59\end{array}$ & $\begin{array}{l}.044 \\
.000\end{array}$ \\
\hline & $\begin{array}{c}5^{\text {th }} \\
\text { grade }\end{array}$ & $\begin{array}{l}3^{\text {rd }} \text { grade } \\
4^{\text {th }} \text { grade }\end{array}$ & $\begin{array}{c}10.02 \\
6.12\end{array}$ & $\begin{array}{l}1.61 \\
1.59\end{array}$ & $\begin{array}{l}.000 \\
.000\end{array}$ \\
\hline Distracters & $3^{\text {rd }}$ grade & $\begin{array}{l}4^{\text {th }} \text { grade } \\
5^{\text {th }} \text { grade }\end{array}$ & $\begin{array}{c}-7.61 \\
-13.45\end{array}$ & $\begin{array}{l}1.94 \\
1.95\end{array}$ & $\begin{array}{l}.000 \\
.000\end{array}$ \\
\hline & $\begin{array}{l}4^{\text {th }} \\
\text { grade }\end{array}$ & $\begin{array}{l}3^{\text {rd }} \text { grade } \\
5^{\text {th }} \text { grade }\end{array}$ & $\begin{array}{c}7.61 \\
-5.84\end{array}$ & $\begin{array}{l}1.94 \\
1.93\end{array}$ & $\begin{array}{l}.000 \\
.008\end{array}$ \\
\hline & $\begin{array}{c}5^{\text {th }} \\
\text { grade }\end{array}$ & $\begin{array}{l}3^{\text {rd }} \text { grade } \\
4^{\text {th }} \text { grade }\end{array}$ & $\begin{array}{c}13.45 \\
5.84\end{array}$ & $\begin{array}{l}1.95 \\
1.93\end{array}$ & $\begin{array}{l}.000 \\
.008\end{array}$ \\
\hline
\end{tabular}


These findings clearly indicate that SVTs are capable of reflecting developmental changes in reading comprehension since higher grade children are better at understanding the deeper level comprehension compared to the lower grades. Hence higher grades have shown a greater percentage of correct responses on the SVTs compared to the lower grades. This development trend has been documented by other studies also (Palmer, 1997).

This technique also appears to have a diagnostic value since it would be able to differentiate between good and poor readers. A good reader would have no difficulties with distinguishing between the four sentence types since he/she would have preserved the meaning of the passage while the poor reader would have preserved only the surface representation of the text passage and not the meaning.

\section{Reading Comprehension and Reading Achievement}

Pearson's product moment correlation was computed to understand the relationship between the performance on reading comprehension, the 4 types of SVTs and the students' recent performance in school tests in English (literature and language). Table 5 findings indicates that reading comprehension as well as all the SVT sentence types were significantly related to English achievement in schools $(\mathrm{p}<0.01)$ despite weak correlations ranging from 0.186 to 0.366 . This reflects that this technique has sufficient convergent validity and can be considered by classroom teachers in identifying children with comprehension difficulties.

Table 5 Correlation between the SVT Variables, Reading Comprehension Total and Performance in English Literature and Language

\begin{tabular}{|c|c|c|c|}
\hline S.No. & Variables & Language & Literature \\
\hline 1. & Total & $.385^{* * *}$ & $.344^{* * *}$ \\
\hline 2. & Originals & $.294^{* *}$ & $.273^{* *}$ \\
\hline 3. & Paraphrases & $.214^{* *}$ & $.204 * *$ \\
\hline 4. & Meaning Change & $.186^{* *}$ & $.207 * *$ \\
\hline 5. & Distracters & $.325^{* *}$ & $.308^{* *}$ \\
\hline
\end{tabular}

Note. $* \mathrm{p}<0.05 ; * * \mathrm{p}<0.01 ; * * * \mathrm{p}<0.001$ 


\section{Conclusions}

Findings from the study clearly outline the usefulness of SVTs in detecting grade and gender differences in levels of reading comprehension. Girls have been found to have better reading comprehension ability as compared to boys. Boys appear to be vulnerable to having reading difficulties at an early age itself and thus steps need to be taken to provide them with opportunities and early stimulation in order to prevent any emerging difficulties. SVTs appear to be sensitive to grade differences and a development trend is clear since comprehension as assessed using the sentence types increased with grades. They could hence prove useful as a diagnostic tool in classroom settings for identifying children with comprehension difficulties. The implications of this research have been to highlight the usefulness of SVTs as a method of assessing reading comprehension. It is relatively easy to construct and can be constructed using any text. It can also prove useful in developing instructional materials for classroom and individualized teaching settings. It can thus help in identifying children requiring remedial help and can be easily used by teachers and non-psychometricians.

\section{Limitations and Future Directions}

The findings from this research are tempered with at least one limitation. For an adequate understanding of reading comprehension, other skills elemental for a good reader, especially word decoding, metacognitive skills and working memory capacity also needs to be assessed since they could underlie comprehension difficulties. Fletcher (2006) emphasized in his article that approaches to the assessment of reading comprehension need to incorporate multiple indicators to enhance the precision with which the underlying latent variables are measured. This article has focused only on the comprehension of the meaning of the text and not on the other above mentioned skills. Subsequent studies need to be sensitive towards a comprehensive assessment of reading ability along with the usage of SVTs as a mode of assessment of comprehension. 


\section{References}

Anders, P. (2002). Towards an understanding of the development of reading comprehension instruction across the grade levels. In $\mathrm{C}$. Roller (Ed.), Comprehensive reading instruction across the grade levels: $A$ collection of papers from the Reading Research 2001 conference, (pp.111132). Newark: International Reading Association.

Beech, J. \& Singleton, C. (1997). The psychological assessment of reading. London: Routledge.

Canadian Council on Learning. Lessons in Learning. (2009, February 18). Why boys don't like to read: gender differences in reading achievement. Retrieved from http://www.ccl-cca.ca/pdfs/Lessons inLearning/ 02_18_09-E.pdf

Child Health News (2004, May 12). New research finds that boys really do have more reading problems than girls. Retrieved January 14, 2013, from NewsMedical: http://www.news-medical.net/news/ 2004/ 05/ 12/ 1493. aspx

Dhar, A. (2012, January 16). Indian students fare poorly in international evaluation tests. The Hindu. Retrieved from http:// www.thehindu.com/news/national/article2804134.ece.

Fletcher, J. (2006). Measuring reading comprehension. Scientific Studies of Reading,10(3), 323-330.

Hess, K. (2007). Reading development and assessment of early literacy: A review of literature. Utah: Utah Department of Education. Retrieved from http://www.schools.utah.gov/eval/documents/Lit_Early LiteracyReview.pdf

Lietz, P. (2006). A meta-analysis of gender differences of reading achievement at the secondary school level. Studies in Educational Evaluation, 32 (4), 317-344.doi10.1016/j.stueduc.2006.10.002

McNamara, D. C. \&Kendeou, P. (2011). Translating advances in reading comprehension research to educational practice. International Electronic Journal of Elementary Education, 4(1), 33-46. Retrieved from http://www.iejee.com/4_1_2011/3_IEJEE_4_1_McNamara_Kendeou. pdf

Moats, L. (1994). The missing foundation in teacher education: Knowledge of the structure of the spoken and written language. Annals of Dyslexia, 41, 81-102. DOI 10.1007/s11145-009-9162-1 
OECD (2010), PISA 2009 Results: Executive Summary. Retrieved from http://www.oecd.org/pisa/pisaproducts/46619703.pdf

Palmer, M. (1997). A comparative study of listening and reading comprehension in children of different age-groups. Pretoria: University of Pretoria. Retrieved January 14, 2013, from http://upetd.up.ac.za/ thesis/ available/etd-10292012-163947/ >

Rice, M. (2009). Making connections: Reading comprehension skills and strategies. Educators Publishing Service. Retrieved from http:// eps.schoolspecialty.com/downloads/research_papers/mc_research.p df

Royer, J. M., Greene, B.A., \& Sinatra, G.M. (1987). The SVT: A practical procedure for testing comprehension. Journal of Reading, 30, 412-422.

Royer, J. M., Hastings, C.N., \& Hooks, C. (1979). A sentence verification technique for measuring reading comprehension. Journal of Reading Behaviour, 11, 355-363.

Wheldall, K. A. (2010). Do more boys than girls have reading problems? Journal of Learning Disabilities, 43(5), 418-429. doi: 10.1177/ 0022219409355477 